\title{
PENGGUNAAN MODEL PEMBELAJARAN SCIENCE ENVIRONMENT TECHNOLOGY AND SOCIETY (SETS) UNTUK MENINGKATKAN KEMAMPUAN BERPIKIR KRITIS DAN SIKAP ILMIAH
}

\author{
MAIMUNAH \\ queenahakim@gmail.com \\ Program Studi Teknik Informatika, Fakultas Teknik, Matematika, dan IPA \\ Universitas Indraprasta PGRI
}

\begin{abstract}
Abstrak. Penelitian ini bertujuan untuk mengetahui peningkatan kemampuan berpikir kritis dan sikap ilmiah siswa pada materi koloid dengan menerapkan model pembelajaran science environment technology and society (SETS). Metode yang digunakan dalam penelitian ini adalah kuasi eksperimen dengan desain penelitian "Pretest-Posttest Nonequivalent Control Group Design". Sampel dalam penelitian ini adalah siswa kelas XI di SMAN 1 Leuwimunding di Kabupaten Majalengka yang berjumlah 62 siswa. Pengumpulan data dilakukan melalui tes tertulis dan lembar observasi. Hasil penelitian menunjukkan bahwa pembelajaran SETS untuk materi koloid dapat meningkatkan kemampuan berpikir kritis siswa dengan N-Gain sebesar 42\% (kategori sedang) dan sikap ilmiah siswa sebesar $72,7 \%$ (baik). Peningkatan kemampuan berpikir kritis siswa kelas eksperimen juga berbeda secara signifikan dari kelas kontrol. Dengan demikian, pembelajaran kimia dengan model pembelajaran SETS harus terus dikembangkan karena dengan mengimplementasikan pembelajaran SETS dapat meningkatkan kemampuan berpikir kritis dan sikap ilmiah siswa
\end{abstract}

Kata kunci: sistem koloid, kemampuan berpikir kritis, science environment technology and society (SETS), sikap ilmiah.

\begin{abstract}
This study aimed to determine the improvement of critical thinking skills and student's scientific attitudes on the colloidal material by applying the learning model science environment technology and society (SETS). The method was used in this study is quasi-experimental research design "Pretest-Posttest Nonequivalent Control Group Design". The sample in this study was a class XI student at one of SMAN in Majalengka, with totaling 62 students. Data collected through a written test and observation sheets. The results showed that SETS learning for colloidal material can enhance student's critical thinking skills with $\mathrm{N}$-Gain of $42 \%$ (moderate category) and the student's scientific attitudewas 72,7 \% (excellent category). Increasing student's critical thinking skills class experiment also differed significantly from the control class. Thus, learning chemistry with SETS learning model should be developed for the implementation of SETS learning can improve critical thinking skills and students' scientific attitudes.
\end{abstract}

Keywords: colloidal systems, critical thinking skills, science environment technology and society (SETS), scientific attitude.

\section{PENDAHULUAN}

Penguasaan Ilmu Pengetahuan Alam (IPA) merupakan dasar bagi perkembangan ilmu pengetahuan dan teknologi pada masa yang akan datang. IPA berkaitan dengan cara mencari tahu tentang fenomena alam secara sistematis, sehingga IPA bukan hanya kumpulan pengetahuan yang berupa fakta-fakta, konsep-konsep, atau prinsip-prinsip saja tetapi juga merupakan suatu proses penemuan (Anwar, 2010: 1). Pendidikan IPA 
diharapkan dapat menjadi wahana bagi siswa dalam mempelajari diri sendiri dan alam sekitar, serta prospek pengembangan lebih lanjut dan penerapannya dalam kehidupan sehari-hari. Hal ini sejalan dengan pendapat Liliasari (2005: 9) yang mengatakan bahwa ide dasar dari kurikulum berbasis kompetensi adalah memperbaiki penguasaan ilmu-ilmu yang dipelajari di sekolah agar dapat diterapkan dalam kehidupan sehari-hari. Idealnya pendidikan IPA itu dapat berimplikasi langsung dalam kehidupan sehari-hari.

Pada masa sekarang ini, pembelajaran IPA kurang dikaitkan dengan isu sosial dan teknologi yang ada di lingkungan dan masyarakat, terutama yang berkaitan dengan perkembangan teknologi dan kehadiran produk-produk teknologi di lingkungan dan masyarakat, serta akibat yang ditimbulkannya. Pengajaran IPA di sekolah semata-mata hanya berorientasi pada tuntutan kurikulum yang telah dituangkan di dalam buku teks. Di sisi lain, kemajuan sains dan teknologi semakin berkembang sehingga menimbulkan dampak kepada lingkungan dan masyarakat. Hal ini menuntut guru untuk mengubah cara pembelajaran yang pasif tersebut kepada pembelajaran yang aktif. Selain itu, dalam proses pembelajaran di kelas siswa didorong untuk mengembangkan kemampuan berpikir. Kenyataan yang terjadi bahwa dalam proses pembelajaran di kelas, bahwa siswa diarahkan kepada kemampuan untuk menghafal informasi. Siswa dipaksa untuk mengingat dan menimbun berbagai informasi tanpa dituntut untuk memahami informasi dan mengaplikasikan informasi tersebut dalam kehidupan sehari-hari (Suyanti, 2010: 41).

Kimia merupakan salah satu cabang IPA yang memiliki peran penting dalam peningkatan mutu pendidikan, khususnya dalam menghasilkan peserta didik yang berkualitas. Kualitas peserta didik tersebut meliputi kemampuan berpikir kritis, kreatif, dan memiliki sikap positif terhadap sains, masyarakat serta tanggap dalam menanggapi isu di masyarakat, yang diakibatkan oleh dampak perkembangan IPA dan teknologi dengan cerdas dan kritis. Untuk dapat menghasilkan peserta didik yang mampu mengembangkan kemampuan berpikir kritis dan sikap ilmiah, maka guru perlu merancang pembelajaran yang dapat memfasilitasi siswa tersebut.

Kemampuan berpikir kritis siswa merupakan kemampuan berpikir tingkat tinggi yang penting untuk dimiliki siswa karena kemampuan berpikir kritis dapat membekali siswa dalam menghadapi persoalan di masa depan bukan hanya dalam pembelajaran di kelas (BSNP, 2007: 12). Dengan kemampuan berpikir kritis, seseorang akan mudah untuk mengolah informasi yang ditemukannya dan digunakan untuk memecahkan permasalahan. Begitu juga dengan sikap ilmiah siswa perlu dikembangkan pada siswa di tingkat sekolah menengah karena di dalam belajar sains tidak hanya sekedar aspek kognitif, aspek afektif juga merupakan bagian yang sangat penting dalam perencanaan, penyampaian, dan evaluasi suatu pembelajaran. Hal ini sejalan dengan yang diungkapkan oleh Carin dan Sund (1997: 3) bahwa pendidikan sains harus melahirkan suatu sikap dan nilai-nilai ilmiah.

Memperhatikan permasalahan di atas, salah satu alternatif model pembelajaran yang dapat digunakan untuk mengatasi masalah di atas adalah dengan menerapkan model pembelajaran SETS. Model pembelajaran SETS ini diharapkan dapat membuat siswa memandang segala sesuatu secara terintegrasi, yaitu dengan memperhatikan unsur-unsur yang terdapat dalam SETS yaitu sains, lingkungan, teknologi dan masyarakat sehingga guru dapat menghubungkan konsep-konsep sains yang diajarkan dengan permasalahan yang terjadi di masyarakat, lingkungan sehari-hari siswa.

Materi kimia koloid mempunyai karakteristik konkrit dengan contoh konkrit. Materi koloid merupakan materi sederhana dan tidak sulit untuk dipelajari oleh siswa, tetapi pada kenyataannya masih terdapat siswa yang mengalami kesulitan memahami materi koloid dengan baik. Hal ini disebabkan karena banyaknya konsep dan contohcontoh pada topik koloid yang dipelajari siswa hanya sekedar hafalan bukan dipelajari 
secara bermakna, dan pembelajaran yang diterapkan masih menekankan pada penyampaian informasi oleh guru, siswa hanya diajarkan menghafal konsep, prinsip, hukum dan rumus-rumus, pemahaman yang dimiliki siswa tidak sebagai hasil pengalaman tapi transfer pengetahuan dari guru ke siswa. Untuk itu perlu inovasi dalam penggunaan model pembelajaran materi koloid, salah satu alternatif model pembelajaran yang bisa digunakan adalah model pembelajaran SETS.

\section{METODE}

Penelitian ini menggunakan metode kuasi eksperimen dengan desain penelitian nonequivalent control group design (Sugiyono, 2009: 116). Kuasi eksperimen adalah penelitian yang menggunakan kelompok subjek secara utuh dalam eksperimen yang secara alami sudah terbentuk dalam kelas dan tidak mengontrol semua variabel yang ada. Nonequivalent control group design, artinya terdapat kelompok kontrol, pada masingmasing kelompok diberi tes awal dan tes akhir dengan perlakuan yang berbeda.

Tabel 1. Desain Penelitian

\begin{tabular}{|c|c|c|c|}
\hline Kelompok & Pretes & Perlakuan & Postes \\
\hline E & $\mathrm{O}_{1}$ & $\mathrm{X}_{1}$ & $\mathrm{O}_{2}$ \\
\hline $\mathbf{K}$ & $\mathrm{O}_{1}$ & $\mathrm{X}_{2}$ & $\mathrm{O}_{2}$ \\
\hline & & & \\
\hline & & & \\
\hline
\end{tabular}

Keterangan:

$\mathrm{O}_{1}=$ Tes Awal

$\mathrm{O}_{2}=$ Tes akhir

$\mathrm{X}_{1}=$ Pembelajaran dengan menggunakan model pembelajaran SETS

$\mathrm{X}_{2}=$ Pembelajaran dengan menggunakan modelpembelajarankonvensional

Subjek Subyek penelitian dalam penelitian ini terdiri dari 62 siswa yang dibagi ke dalam kelas eksperimen sebanyak 31 siswa dan kelas kontrol sebanyak 31 siswa, penelitian ini dilakukan pada tanggal 13-29 Agustus di salah satu SMAN di Kabupaten Majalengka. Instrumen yang digunakan dalam penelitian ini adalah instrumen tes kemampuan berpikir kritis sebanyak 8 soal tes essay dan lembar observasi sikap ilmiah siswa.

\section{HASIL DAN PEMBAHASAN}

Penelitian ini dilakukan selama 5 kali pertemuan. Pada pertemuan pertama dilakukan pretest untuk mengetahui kemampuan berpikir kritis siswa, kemudian dilakukan implementasi pembelajaran sebanyak 3 kali pertemuan masing-masing pada kelas eksperimen dan kontrol. Selama proses pembelajaran, dilakukan penilaian terhadap sikap ilmiah siswa dan setelah pembelajaran selesai, pada pertemuan ke-5 dilakukan posttest untuk mengetahui peningkatan kemampuan berpikir kritis siswa.

Berdasarkan hasil penelitian yang telah dilakukan, diperoleh data skor pretest, posttest, dan N-Gain peningkatan kemampuan berpikir kritis siswa pada kelas eksperimen (E) dan kontrol (K) secara keseluruhan. 
Tabel 2. Pretest, Posttest, dan N-Gain Kemampuan Berpikir Kritis Siswa

\begin{tabular}{|c|l|c|c|c|c|c|}
\hline \multicolumn{2}{|c|}{ Data } & $\begin{array}{c}\text { Jml } \\
\text { Siswa }\end{array}$ & Skor min & $\begin{array}{c}\text { Skor } \\
\text { maks }\end{array}$ & $\begin{array}{c}\text { Rata- } \\
\text { rata }\end{array}$ & $\begin{array}{c}\text { Std. } \\
\text { deviasi }\end{array}$ \\
\hline \multirow{4}{*}{ E } & Pretest & 31 & 29,17 & 45,83 & 38,98 & 4,10 \\
\cline { 2 - 7 } & $\begin{array}{l}\text { Postte } \\
\text { st }\end{array}$ & 31 & 45,83 & 87,50 & 64,52 & 10,08 \\
\cline { 2 - 7 } & \multicolumn{2}{|c|}{$\%$ N-Gain } & \multicolumn{2}{|c|}{42} & \multicolumn{2}{c|}{ Kategori sedang } \\
\hline \multirow{4}{*}{ K } & Pretest & 31 & 33,33 & 45,83 & 39,93 & 4,66 \\
\cline { 2 - 7 } & $\begin{array}{l}\text { Postte } \\
\text { st }\end{array}$ & 31 & 45,83 & 70,83 & 56,59 & 7,47 \\
\cline { 2 - 7 } & \multicolumn{2}{|c|}{$\%$ N-Gain } & \multicolumn{2}{|c|}{28} & \multicolumn{2}{|c|}{ Kategori rendah } \\
\hline
\end{tabular}

Berdasarkan hasil analisis rata-rata perolehan skor pretest kemampuan berpikir kritis pada kelas eksperimen dan kelas kontrol ditemukan hasil yang tidak berbeda secara signifikan. Kelas eksperimen dan kelas kontrol masing-masing memperoleh rata-rata nilai 38,98 dan 39,92. Perolehan nilai di kelas eksperimen maupun kelas kontrol sebelum pembelajaran menunjukkan bahwa siswa telah memiliki pengetahuan awal yang berkaitan dengan konsep yang akan dipelajari.

Berdasarkan hasil analisis terhadap skor posttest,nilaiyang diperoleh kelas eksperimen dan kelas kontrol mengalami peningkatan. Namun, terdapat perbedaan nilai rata-rata pada kedua kelompok kelas tersebut. Kelas eksperimen yang menggunakan model pembelajaran SETS memiliki rata-rata skor sebesar 64,52, sedangkan kelas kontrol memiliki rata-rata skor 56,59. Berdasarkan nilai tersebut dapat disimpulkan bahwa ratarata peningkatan kelas eksperimen lebih tinggi dibandingkan dengan rata-rata peningkatan kelas kontrol.

Kemampuan berpikir kritis siswa pada kelas eksperimen dan kelas kontrol sebelum dan setelah pembelajaran juga dapat dilihat berdasarkan uji hipotesis. Uji hipotesis dalam penelitian ini menggunakan uji nonparametrik (Mann-Whitney), hal ini karena data pretestdan data posttestpada kelas eksperimen dan kelas kontrol tidak terdistribusi normal. Uji normalitas menggunakan uji Kolmogorv-Smirnov dengan menggunakan program SPSS for Windows versi standar 16. 00.

Tabel 3. Hasil Uji Perbedaan Rerata Pretest dan Posttest

\begin{tabular}{|c|c|c|}
\hline Skor & Pretest & Posttest \\
\hline P-value/Sig & 0,398 & 0,001 \\
\hline Kesimpulan & Tidak berbeda signifikan & $\begin{array}{c}\text { Berbeda } \\
\text { signifikan }\end{array}$ \\
\hline
\end{tabular}

Berdasarkan Tabel 3, pada uji signifikansi data pretest diperoleh signifikansi $(\alpha)$ sebesar $0,398>0,05$, maka $\mathrm{h}_{0}$ diterima, sehingga dapat disimpulkan bahwa kemampuan berpikir kritis siswa sebelum pembelajaran pada kelas eksperimen dan kelas kontrol relatif sama atau tidak berbeda secara signifikan. Dengan demikian dapat disimpulkan bahwa kemampuan awal siswa pada konsep koloid antara kelas eksperimen dan kontrol adalah sama. Hal ini sesuai dengan salah satu karakteristik penelitian yang bersifat eksperimen seperti dikemukakan oleh Russefendi (1998:39), bahwa equivalensi subjek dalam kelompok-kelompok yang berbeda perlu ada, agar bila ada hasil berbeda yang diperoleh oleh kelompok, itu bukan disebabkan karena tidak equivalennya kelompokkelompok tersebut, tetapi karena adanya perlakuan. 
Berdasarkan tabel 3 didapat signifikansi $(\alpha)$ data posttest sebesar $0,001<0,050$, maka $\mathrm{h}_{0}$ ditolak, sehingga dapat disimpulkan bahwa terdapat perbedaan yang signifikan antara kemampuan berpikir kritis siswa yang belajar menggunakan model pembelajaran SETS dengan siswa yang belajar menggunakan model pembelajaran konvensional. Kemampuan berpikir kritis siswa yang belajar melalui model pembelajaran SETS lebih baik dibandingkan kemampuan berpikir kritis siswa yang belajar dengan model pembelajaran konvensional.

Berdasarkan hasil perhitungan gain ternormalisasi (N-Gain) pada tabel 2 kemampuan berpikir kritis siswa kelas eksperimen dengan kelas kontrol menunjukkan bahwa rata-rata N-Gain kelas eskperimen $42 \%$ dan kelas kontrol 28\%. Dari skor tersebut diketahui bahwa N-Gain kelas eksperimen berada pada kategori sedang, sedangkan NGain kelas kontrol berada pada kategori rendah. Perbedaan perkembangan kemampuan berpikir kritis yang dialami oleh siswa setelah proses pembelajaran disebabkan karena tahapan SETS penuh dengan aktivitas berpikir, berargumen, dan berdiskusi. Selain itu, Zulfiani (2003: 69) mengatakan bahwa untuk mengembangkan kemampuan berpikir kritis siswa dapat dilakukan melalui siklus belajar yang meliputi tiga tahap yaitu eksplorasi, pengenalan, dan tahap aplikasi. Ketiga tahapan tersebut ada dalam tahapan SETS. Kemampuan yang dimiliki siswa ini tidak terlepas dari peran aktif siswa dalam mencari informasi untuk diaplikasikan dalam menyelesaikan masalah.

Hal ini sesuai dengan yang dikatakan oleh Glathorn dan Baron (Hanaswati, 200: 75), bahwa cara berpikir siswa dapat ditingkatkan dengan cara memberi masalah yang menuntut siswa memanfaatkan proses-proses pemecahanan masalah. Dalam proses pembelajaran dengan model pembelajaran SETS siswa dituntut untuk dapat memecahkan masalah atau isu-isu yang berkembang di masyarakat. Kemampuan pemecahan masalah ini dikembangkan pada setiap tahap SETS, yaitu melalui pemunculan isu-isu permasalahan pada tahap pendahuluan, berdasarkan permasalahan yang disajikan kemudian siswa didorong dan dimotivasi untuk memberikan/menjawab pertanyaan. Pertanyaan yang diberikan siswa kemudian dijadikan interaksi lebih lanjut. Setelah itu siswa melakukan tugas penyelidikan dalam kelompok penelitian, kemudian mempresentasikan hasil penelitian tersebut.

Data sikap ilmiah siswa diperoleh dari pengisian lembar observasi sikap ilmiah siswa selama proses pembelajaran. Lembar observasi terdiri 20 butir pernyataan, yang didalamnya memuat beberapa indikator sikap ilmiah. Setelah melakukan pengisian pengisian lembar observasi sikap ilmiah, didapatkan data rata-rata sikap ilmiah pada kelompok eksperimen dan kelompok kontrol secara keseluruhan.

Tabel 4. Hasil Lembar Observasi Sikap Ilmiah Siswa Kelas Eksperimen dan Kontrol

\begin{tabular}{|c|c|}
\hline Eksperimen & Kontrol \\
\hline 72,7 & 60,7 \\
\hline Baik & Cukup \\
\hline
\end{tabular}

Berdasarkan tabel 4, didapatkan bahwa skor rata-rata sikap ilmiah siswa kelas eksperimen sebesar 72,7 (kategori baik) sedangkan skor rata-rata kelas kontrol sebesar 60,7 (kategori cukup). Hal ini menunjukkan bahwa siswa pada kelas eksperimen dan kelas kontrol memiliki sikap ilmiah yang baik. Namun rata-rata sikap ilmiah pada kelas eksperimen lebih tinggi jika dibandingkan dengan kelas kontrol. Kondisi tersebut dimungkinkan karena sikap manusia dalam merespon sesuatu tidak selalu sama. Hal ini terjadi karena sikap yang terdapat pada manusia dipengaruhi oleh beberapa faktor yaitu 
keinginan, pengetahuan, kebiasaan, interaksi sosial yang terjadi dalam kelompok atau di luar kelompok dapat mempengaruhi atau membentuk sikap baru (Gerungan: 1988: 166).

Perbedaan skor sikap ilmiah pada kelas eksperimen dengan kelas kontrol juga dimungkinkan karena selama pembelajaran siswa sama-sama difokuskan pada model pembelajaran yang sedang dilakukan, siswa mengikuti proses belajar dengan metode ilmiah dari awal hingga akhir dengan baik. Perbedaan skor sikap ilmiah pada kelas eksperimen dan kelas kontrol disebabkan karena adanya perbedaan frekuensi dan perlakuan yang diberikan. Seperti halnya pendapat Fuady (2007, dalam Hulu, 2009: 101) yang menyatakan bahwa proses dan frekuensi belajar yang menyenangkan dapat meningkatkan motivasi belajar yang tinggi bagi siswa sehingga memberikan hasil belajar yang berkualitas. Untuk kelas eksperimen diberikan perlakukan pembelajaran dengan model pembelajaran SETS yang didalamnya terdapat kegiatan diskusi, demosntrasi, dan praktikum, dan kelas kontrol dengan model pembelajaran konvensional yang didalamnya juga terdapat kegiatan praktikum. Kegiatan praktikum ini dapat dapat melatih siswa untuk melakukan kerja ilmiah, seperti pengamatan, identifikasi, dan menjelaskan pemecahan masalah.

Hal ini sesuai dengan pernyataan Amin (1994: 84) bahwa untuk memperoleh ilmu pengetahuan tidak hanya dengan cara membaca, namun juga melalui penyelidikan fenomena dan fenomena kehidupan secara langsung. Penyelidikan yang dilakukan dengan cara yang sistematis melalui metode ilmiah akan menumbuhkan sikap ilmiah. Depdiknas (2002: 15) memperkuat pernyataan Amin bahwa belajar sains dapat membantu siswa untuk memahami alam dan gejalanya berkaitan dengan penelitian dan penyelidikan sehingga dapat menumbuhkan sikap ilmiah siswa.

\section{PENUTUP}

Berdasarkan hasil penelitian dan pembahasan yang telah diuraikan diperoleh kesimpulan sebagai berikut:

1. Model pembelajaran SETS dapat meningkatkan kemampuan berpikir kritis siswa. Secara keseluruhan kemampuan berpikir kritis siswa meningkat dengan N-Gain sebesar 42\% (kategori sedang), sedangkan kelas kontrol dengan N-Gain sebesar 28\% (kategori rendah). Secara statistik menunjukkan bahwa terdapat perbedaan yang signifikan antara rata-rata kemampuan berpikir kritis siswa pada kelas eksperimen dan kelas control

2. Secara keseluruhan, hasil skor rata-rata sikap ilmiah siswa dengan model pembelajaran SETS sebesar 72,7\% (kategori baik)

\section{DAFTAR PUSTAKA}

Amin, M. 1994. Mengajarkan Ilmu Pengetahuan Alam dengan Metode Discovery and Inkuiri. Jakarta: Departemen Pendidikan dan Kebudayaan.

Anwar, M. 2010. Penerapan Pendekatan SETS (Science Technology and Social) pada Pembelajaran Fisika pada Diklat Guru Mapel Fisika MA.

BSNP, 2007. Peraturan Menteri Pendidikan Nasional Republik Indonesia Nomor 20 Tahun 2007 Tentang Standar Penilaian Pendidikan. Jakarta.

Carin, A. ,\& Sund, B. 1997. Teaching Science Through Discovery. Columbus, Ohio: Merill Publishing co.

Gerungan. 1998. Psikologi Sosial. Bandung: Eresco

Hanaswati. 2000. Pengembangan Model Pembelajaran Pencemaran Air Untuk Meningkatkan Keterampilan Berpikir Kritis Siswa Madrasah Aliyah Melalui Belajar Kooperatif. Tesis PPS UPI. Bandung. Tidak diterbitkan. 
Hulu, F. L. W. 2009. Penggunaan Praktikum Konfrontatif untuk Memfasilitasi Peningkatan Penguasaan Konsep dan Sikap Ilmiah Siswa Kelas VII pada Pokok Bahasan Organisasi Kehidupan. Tesis PPS UPI Bandung: Tidak Diterbitkan.

Liliasari. 2005. Membangun Keterampilan Berpikir Manusia Indonesia melalui Pendidikan Sains (Pidato pengukuhan Guru Besar Tetap IPA). Bandung: UPI.

Russefendi, T. E. 1998. Statistika Dasar untuk Penelitian Pendidikan. Bandung: Alfabeta. Sugiyono. (2009). Metode Penelitian PendidikanPendidikan Kuantitatif, Kualitatif, dan R\&D. Bandung: Alfabeta.

Suyanti, D. R. 2010. Strategi Pembelajaran Kimia. Yogyakarta: Graha Ilmu.

Zulfiani. 2003. Model Pembelajaran Teknologi DNA untuk Meningkatkan Keterampilan Berpikir Kritis Mahasiswa. Tesis PPS UPI Bandung. Tidak diterbitkan. 